\title{
THE DOG, THE HORSE AND THE CREATION OF MAN
}

\author{
Yuri Berezkin
}

\begin{abstract}
A story that described the creation of man became known to at least some inhabitants of the Eurasian Steppe zone not later than the early II millennia B.C. Not a fragment of it survived across most of this area, and our reconstruction is based on the evidence from the areas to the north and to the south of the Steppe Belt. The texts in question share many specific details and the probability of their independent emergence looks negligible. At the same time the people to whom the story was familiar in the 19th and 20th century could definitely not have borrowed it from each other in recent times.

The only way to reconstruct the mythology of the people who lived in the past is a search of its survivals in the later folklore. The analysis of ancient iconography or scraps of evidence preserved in the early written sources is not enough for the reconstruction of the plots of complex tales.
\end{abstract}

Keywords: creation myth, creation of man

A story that described the creation of man became known to at least some inhabitants of the Eurasian Steppe zone not later than the early II millennia B.C. Not a fragment of it survived across most of this area, and our reconstruction is based on the evidence from the areas to the north and to the south of the Steppe Belt. The texts in question share many specific details and the probability of their independent emergence looks negligible. At the same time the people to whom the story was familiar in the 19 th and 20 th century could definitely not have borrowed it from each other in recent times and had hardly been able to do it before. To most of them, however, this tale could become known thanks to the contacts with those inhabitants of the Eurasian steppe zone who probably spoke the Indo-European languages and were displaced or assimilated by the Turkic and Mongolian peoples during the I millennium A.D. The only groups who possibly inherited it directly from their language ancestors, now live in the Pamir - Hindu Kush area.

The corresponding tales can be clustered, both geographically and thematically, according to two main traditions, the Southern and the Northern ones. 
Some texts related to the Southern tradition are recorded far to the north or to the west of the main area of its spread but have the same basic structure.

\section{TEXTS OF THE SOUTHERN TRADITION}

The example texts of the Southern tradition are recorded from the Northeastern and Middle India to the Caucasus (Figure 1).

The South Asian cases are numerous and detailed. They are mostly found among the people of the Munda language family in the Indian states of Bihar and Jharkhand, in particular among the Mundari, Korku, Santali, Birjia, Birhor and Kharia. No traces of this myth were recorded among most of the Dravidian people, the only exceptions being the Gondi and the Oraons. The Northern Dravidian Oraon (the Kurukh) language and the Mundari language are spoken in the nearby villages. The Oraons could easily have borrowed this tale from the Mundari, and it was recorded among them several times, all versions being more or less identical with the Mundari ones. The Gondi who speak Central Dravidian language and who were not in an intensive cultural interaction with any Munda group have only one version. Some versions have been recorded among the Tibeto-Burman groups of Nepal, the Northeast India and adjacent areas of Mianmar, in particular among the Limbu, Kachari and Mizo (other name Lushei), and among the Khasi of Meghalaya state. The latter speak the Austroasiatic language but of a totally different branch than the Munda. No Tibeto-Burman or Khasi version demonstrates the full set of motifs typical for the most extensive Munda and Oraon versions.

The basic plot of the story was known to the Bhili, more precisely to the Balela-Bhilala of Gujarat and Madhya Pradesh. Now the Bhili speak an IndoAryan language but their cosmological tale shares basic episodes with the Mundaic, Central Dravidian and Southeast Asian myths (Kapp 1986: 266-269; Koppers \& Jungblut 1976: 199-201). It is not excluded (though not certain, of course) that the original language of the Bhili belonged to the Munda family.

Almost all variants recorded in India and Nepal were studied by Dieter Kapp (1977). Additional materials were found by Toshiki Osada (2010). The only text that remained unnoticed by them is of the Kachari (Soppitt 1885: 32). The number of the recorded versions is the highest among the Oraons (10), Mundari (6), Santali (3) and Korku (3).

As mentioned above, the plot in question was not known to the Indo-Aryan people of South Asia and is absent both in the early written sources and in the present day folklore. At the same time it was recorded among the Dardic people of Eastern Hindu Kush, in particular among the Kho and the Kalash (Jettmar 


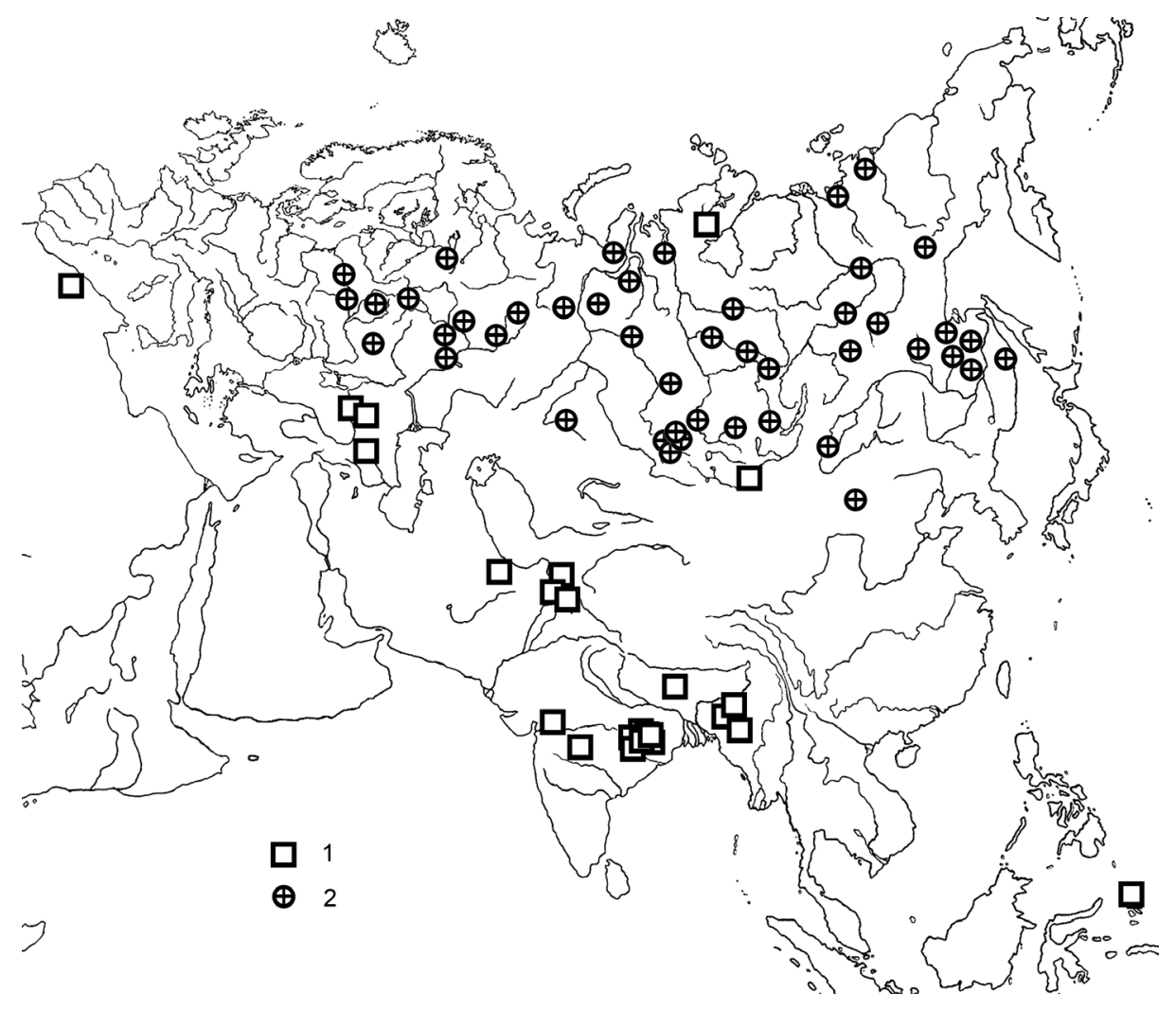

Figure 1. The location of the traditions that contain the northern and the southern variants of the myth about the creation of the man. 1 - the guard (usually a dog) successfully drives away the antagonist who tried to destroy God's creation or the dog is created from the same substance as the man; 2 - The guard (usually a dog) cannot defend human figures created by God.

1986: 359, 444). The Dardic languages pertain to the Indo-Iranian branch of the Indo-European stock but occupy a special position, probably being slightly nearer to the Indo-Aryan than to the Indo-Iranian branch. I could not find any version among the Nuristani (Kafir) traditions of Afghanistan but we should take into consideration our relatively poor knowledge of the Nuristani folklore.

The typical Indian variant is as follows. God makes of mud figures of a man and a woman and puts them to dry. A horse or two horses, often winged, come and break the figures. The creator makes a dog or two dogs who drive the horses away. The horse is punished by being deprived of its wings and 
obliged to serve the man, and to be harnessed and beaten. The horse wanted to destroy the man just because it was afraid that the man would harness it. In one of the Korku stories trees try to destroy the man, being afraid that the man would begin to cut them.

One of the Dardic (the Kho) versions is quite similar to the Indian ones. Before the creation of the man, the world was populated by horses. They tried to trample down the figure of Adam that was made of mud but the dog did not let them to do it and until now remains the guard of the man. The navel on the human body is the trace of the horse's hoof (Jettmar 1986: 444).

To this main group of texts there should be added others that lack some details, e.g. the guard is not mentioned at all or (in some Mundari versions) it is not a dog but a tiger or a spider. Among the Dards (Jettmar 1986: 359) and among the Munda-speaking groups such versions with minor alterations exist along with the typical ones. Among the Limbu the complete texts (with the dog as a guard) are not known. According to the Limbu myth, Niwa-Buma made the first man out of gold and he was perfect, but the envious horse monster broke the figure. Niwa-Buma created the man anew of ashes and chicken dung, and punished the horse. Now it has to walk on four legs and not on two as before and is a beast of burden (Hermanns 1954: 10-11). The Limbu text is rather similar to the Pamir (the Wakhi) version according to which the man created by God was handsome but the covetous horse kicked the half-ready figure and because of this all people have some physical imperfection. God punished the horse by making it the servant of the man. This information was kindly supplied by the late Bokhsho Lashkarbekov in February 2005. Among the Mizo, Kachari and Khasi the antagonists who try to destroy human figures are a snake, an evil spirit, or brothers of the creator (Kapp 1977: 50; Shakespear 1909: 399; Soppitt 1885: 32). The role played by the dog in these texts is the same as in most of the others. In South Asia the most distant from the Mundari versions, both geographically and by its content, is the tradition of the Barela-Bhilala. A goddess makes human figures, "the sky queen of the eagles" tries to destroy them, a male personage kills her, and the high god inserts souls into the human bodies (Kapp 1977: 46).

Myths about the creator (or his messenger) who took some mud, made the figures of human beings and left them for a while to bring the souls are recorded among the Loda and Galela of Halmahera Island (Indonesia, the Northern Malucu). When the evil spirit broke the figures, the creator made two dogs from his (i.e. the evil spirit's) excrements and they drove him away after which the humans were made alive (Baarda 1904: 442-444; Kruijt 1906: 471). This Indonesian variant is similar to some Indian ones, especially to the Khasi text, but it can be left aside. The name of the antagonist is O Ibilisi (from Arabic 
"Iblis", the Devil) and it means that the story reached the Maluku after the advent of the Islam. When and how it happened is not essential for our topic.

Moving to the west from South Asia, we should mention "a late Zoroastrian legend" from Iran (Litvinski \& Sedov 1984: 166). After creating the first man Gaiomard, Ormuzd commissioned seven sages to guard him from Akhriman but they could not fulfill the task. So Ormuzd put the dog Zarringoš ("yellow ears") as a guard and since then this dog protects from demons the souls who go to the Beyond. There is no such story in "Avesta" though it does not exclude the possibility that it could exist in the oral tradition from the early time.

Another cluster of folklore records related to the story about the creation of man by God and a brave dog who saved human figures from destruction is localized in the Caucasus. Among the Abkhazians the story was discovered in the 1990s. One text was recorded by the ethnologist Marina Bartsyts from her mother, another by the folklorist Valentin Kogonia (I am grateful to Marina Bartsyts and Zurab Japua for this information). The version recorded by Bartyts is as follows. In the time of the creation of the world the man was made of mud but the devil sent horses to trample him because otherwise the man would torment them all the time. The man managed to take a handful of mud from his abdomen and threw it to the attackers. The lumps of mud turned into dogs and drove the horses away. In Kogonia's version (published in Abkhazian), the dog also defends the man by its own initiative and not by the order of the creator. God made the man out of mud. The devil warned the horses, "If the man becomes alive, you are doomed, kill him!" The horses rushed at the man but the dogs drove them away. That's why the man and the dog are considered to be close to each other.

The Swan variant was never recorded in detail. It was heard by an archaeologist Alexei Turkin in Swanetia in 2004 from an old man, R. Shamprioni being the interpreter. During a conference in Saint Petersburg (October 2012) A. Turkin told me that the story was practically identical with the Abkhazian one.

The Armenian version is drawn to the study thanks to the invaluable help of Lilith Simonian, a folklorist from Yerevan. This tale was recorded in 1941 in Lori near the Georgian border and recently published in Armenian (Zhamkochian 2012: 138-140). God sent angels to bring the mud, made the figure of Adam and put it to dry. Devils told horses to destroy the figure, otherwise the man would put them to work. God sent the angels again and this time the devils spat on the mud but God wringed it out and the saliva turned into the dog who drove the horses away. The place on the human body from which the devil's saliva ran out is the navel. This text shares specific motifs both with the Abkhazian versions (dog emerges spontaneously out of the substance extracted 
from the body of the man) and with the Dardic (the Kho) version in which the origin of the human navel is also explained.

The westernmost text that contains a significant part of our plot is registered among the Arabs of the Tiaret plateau in northern Algeria (Aceval 2005: 10-11). God made the man's figure out of mud. Satan looked at it and spat in disgust, the place where his spittle fell turned into the navel. When angels brought the human soul to be inserted into the body one of them noticed a dark spot, scraped it off and the substance turned into the dog. Because the dog is created both from Satan's spittle and from the same substance as the man himself, it is considered unclean but remains the best friend of the man.

The easternmost Eurasian text related to our anthropogenic tale is found in western Mongolia. The publisher of its Russian translation kindly let me know that the text had been recorded in 1983 in Ubsunur Aimak from the Dörbet man, the Dörbet being one of the groups of the Oirats . God modeled of mud two human figures. The cow came and caught one figure with a horn, it fell down and broke. The fragments turned into the dog, and since then the dog barks at the cow. The dog and the man have common origin, that's why their bones are similar (Skorodumova 2003: 51-52). The major difference between the Oirat tale from one side, and the Caucasian and South Asian versions from the other side, is the replacement of the horse with the cow. Such a replacement is logical but we'll address this topic a little bit later.

The last version of the tale that should be mentioned in this section was recorded in the far North among the Nganasans and represents the only Siberian case of its kind. The primeval mother gave birth to a child, a small branch of willow. Her husband put it to grow but "The disease came and spoiled it." The man asked his wife to give him another child so that the latter would defend the former. The second child proved to be a reindeer without horns. He asked his father to give him horns to fight the worms and evil beasts, received one horn of ivory and another of stone and destroyed the beasts (Popov 1984: 42-43). Another version of the same story was published by B. Dolgikh (1976: 39-44). It contains similar episodes and describes the antagonist who tried to destroy the "blade of grass child" as "something flying". Though neither the horse nor the dog is mentioned in the Nganasan myth, its structure fits the southern pattern according to which the guard successfully drove away the antagonist. 


\section{THE AGE OF SPREAD OF THE SOUTHERN TRADITION}

To establish the terminus ante quem for the dispersal of the Southern tradition across Eurasia, the distribution of variants recorded among the different groups of the Munda are of crucial significance. Now most of the "tribal" people of India are dispersed at vast territories, some groups changed their linguistic affiliation during the last centuries. However, the areas where the number of speakers of the corresponding languages is the highest are mostly the same as they were in the past (Osada \& Onishi 2010). The principal area of the spread of the Munda languages is the Chota Nagpur plateau (state of Jharkhand with adjacent territories). The Santali, Ho, Mundari, Birhor, Asur (including Birjia) and other groups that speak languages of the northern branch of the Munda live here. To the south, mostly in the Koraput district of Orissa state, Bondo, Sora and other languages of the southern branch of the Munda are located (Figure 2). Much to the west, in Maharashtra state, the Korku language is localized, which belongs to the northern branch. The position of Kharia and Juang is not certain. Formerly these languages were classified as belonging to the southern Munda but according to the recent classification they stand nearer to the Northern division (Diffloth 2005). Ilia Peiros (Santa Fe Institute) also classifies the Kharia and Juang as the Northern Munda. His conclusions are based on the 100 words list of Morris Swadesh according to the glottochronological formula of Sergei Starostin (personal communication, October 2010). The Juang speakers live in the northern Orissa, and the Kharia is spoken practically across the same area as the Mundari (Peterson 2009: VI-VIII).

Initially, the Munda family broke into the southern and northern branches, then Kharia and Juang split from the northern branch, after this the Bondo and Sora separated from each other and at last the Korku lost contact with other languages. The lexicostatistics gives only approximate assessments of age but still helps to create a rough chronology and to establish the successive steps of the splitting of language branches. The disintegration of the Munda family began in the early II millennium B.C. (the separation of the northern and southern branches), while the isolation of the Korku took place in the mid I millennium B.C.

The myth about the creation of the human figures and an attempt to destroy them is recorded among the northern Munda including the Korku. It should be noticed, that the Korku mythology is poorly known while the materials on the Bondo and Sora are rather rich. The fact that three versions have been found among the Korku indicates that the tale is very popular there. At the same time we can be sure that the Bondo and Sora were not familiar with it. It means that the Munda could have adopted the tale between ca. 1700 (after 
the separation of the southern Munda) and 900 B.C. (before separation of the Korku). The age estimations, as I have already mentioned, are approximate but both III millennium B.C. and the middle of the I millennium B.C. are practically excluded. The tale is not recorded among the Juang and the only Kharia version is similar to the versions of the Mundari (Pinnow 1965, no. 26: 142-143). Because the Kharia were in contact with the Mundari, the existence of the version of the tale in their case is not significant. But the absence of the tale among the southern Munda is significant just because these groups were not in contact with the northern Munda for a long time.

Though the Munda can definitely be considered as the main South Asian possessors of the story in question, they must also have borrowed it. Firstly, this tale is absent among the southern Munda and among other Austroasiatic people besides the Khasi. Secondly, the horse, whose role in this story is very important, was brought to South Asia by the Indo-Europeans. Bones of the Equidae from Harappa sites do not belong to the domestic horse (Bryant 2001: 170-175; Parpola \& Janhunen 2010: 435). No horses are buried in Gonur, Turkmenistan (ca. 2150-1500), though dog, donkey and sheep burials are common. The isolated horse bones are found but their stratigraphic position is not certain (Dubova 2012).

The cultural change on the western periphery of the Indian subcontinent becomes visible since ca. 1400 B.C. and was probably related to the coming of the Eastern Iranians (Kuzmina 2008: 300-305; 2010: 34). The first Indo-Aryans remain invisible archaeologically, just as the traces of many other migrations known from written sources or linguistic data. However, the linguists and archaeologists almost unanimously put the time of the Indo-Aryan arrival to India inside the interval between 1900 and 1200 B.C. (Bryant 2001: 218, 224, 229-230) that corresponds to the suggested time of the spread of the war chariot and development of the nomadism (Kuzmina 2000).

As it was told already, there are no stories about an attempt to destroy human figures made by the deity neither in Sanskrit texts nor in the folklore of modern people who speak the Indo-Aryan languages, besides the BarelaBhilala, though slight reminiscence of such a plot has possibly been preserved in the Hinduism. According to one of the legends, the horse had wings and could fly, and neither men nor gods were able to catch it. Indra was in need of horses to pull his cart and asked a saint to deprive the horses of their ability to fly (Howey 1923: 214).

Because the full-bodied versions of the tale in question have been recorded among the speakers of Dardic languages of Eastern Hindu Kush, it is probable that this tale was brought to India by the Dards or some group closely related to them. The traces of these people were wiped off by the Indo-Aryans who spoke 


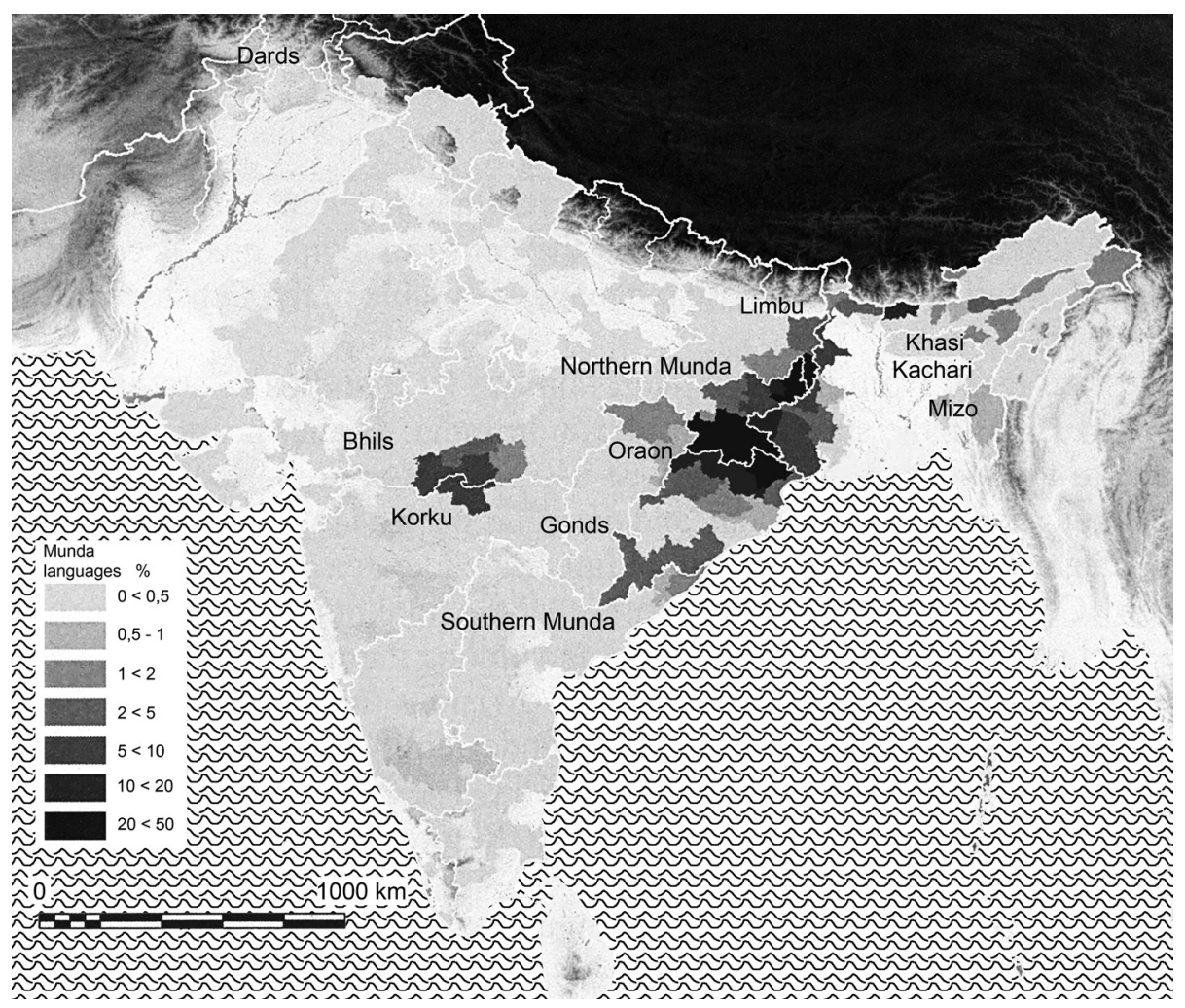

Figure 2. The present day spread of the Munda languages (after Osada \& Onishi 2010, fig. 10) and the location of selected ethnic groups of South Asia.

a kindred language and came later. The time of the first Indo-European arrival to India fits well the suggested time of the borrowing of the tale by the native people of the sub-continent, i.e. between the disintegration of the Proto-Munda and the split of Korku from Northern Munda. According to the areal pattern of the spread of the story in South Asia (mainly between the Himalaya and the eastern parts of Madhya Pradesh and Jharkhand), it was brought by the groups which moved along the Ganges Valley.

As it was mentioned, the Wakhi are the bearers of the story in the Pamir area. They could have inherited it from their Saka ancestors or borrowed it from the Dards. It is difficult to say if the Eastern Iranians of Turkestan were 
familiar with the story, but it is very probable that this myth had been formerly widespread at least in some areas of the Eurasian steppes.

As for the Algerian and the Caucasian versions, they are clearly influenced by the "Abrahamic" mythology, and the tale probably reached Maghreb only after it had been integrated into the folk Christian or even Islamic tradition. The Loda and Galela versions from Maluku and the Armenian and Arabic versions share the motif of the dog created from the antagonist's excreta (his dung or saliva), and this detail looks like a late addition spread with the Islam. It would be wrong, however, to seek the origins of these stories in the Near East. Neither the Bible nor any other early texts from the Near East contain anything like this while the South Asian cases have nothing to do with the Christianity or Islam.

Another argument in favor of the early spread of the tale across Eurasia are the exclusive parallels between the westernmost (the Caucasus and Algeria) and the easternmost (Mongolia) versions. In all these cases the dog was not put by the creator to guard the figure of the man but emerged itself at the very moment when the antagonist attacked the creation. It is also only in these variants that the affinity of the dog and the man is specially underlined. Here it is appropriate to remind of the extremely high status of the dog in the Zoroastrian tradition (Boyce 1989: 145-146; Chunakova 2004: 203; Kriukova 2005: 202-205). Because this tale has a limited, narrowly localized spread in western Mongolia, the probability of its emergence in Mongolia and the transmission to the Caucasus with the Genghiz Khan warriors can be practically ignored. It is much more plausible that both at the western and eastern peripheries of the great steppe the tale was ultimately inherited from the earlier inhabitants of this region, all or most of whom spoke the Indo-European languages. Only these people could contact the natives of the Caucasus, the South Asian Munda and some groups in Mongolia from whom the story was ultimately inherited by the Oirats.

When it comes to the Nganasan myth with its southern parallels, its Arctic location is not so difficult to explain as it could seem. The Nganasan ethnogenesis is complex with different components merged, including the Tungus, the Samoyed (which language was adopted) and a local substratum of unknown linguistic affiliation (Dolgikh 1952). There are no data in favor of language contacts between the ancestral Samoyed and the Indo-European groups of the steppes besides a very hypothetical possibility of such contacts with the (proto-)Toharians (Napolskikh 1997: 82). However, the archaeological materials evidence a movement of the descendents of the Pazyryk culture of Altai far to the north (Molodin 2003: 148-178). In any case the people of the taiga and tundra zones could have borrowed the variant of the myth from the inhabit- 
ants of the steppe. Later this variant was almost completely superseded with the Northern (the European-Siberian) tradition and survived only in Taimyr which this tradition had not reached.

An argument in favor of the existence of historic connections between all the Old World texts that have been discussed is the lack of analogies in the New World. One text of the Plains Ojibwa in Canada slightly reminds the Eurasian ones. Weese-ke-jak makes a human figure out of stone and steps back to admire it. The bear rubs itself against the figure, it falls down and is broken. Weeseke-jak makes a new figure out of mud, and that's why human beings are weak (Simms 1906: 338-339). The similarity with the Eurasian texts is, however, superficial. Among the Ojibwa the essential detail is not the interference of a particular antagonist into the creation of the man but the opposition between the durable and the fragile materials to make the man. Such an opposition is typical for stories that explain the origin of death in the North America's Northwest (Berezkin 2010: 17-21) but this Plains Ojibwa text alone speaks about the breaking of human figure.

\section{THE HORSE IN THE INDO-EUROPEAN WORLDVIEW}

It was told above that the replacement of the horse by the cow in the Oirat version looks logical.

Among the Mongolian and Turkic people of Siberia, Kazakhstan and Central Asia the horse has an almost sacred status and cannot have any negative associations, while the bull or the cow can. In some of the Kazakh, Altai, Tuvinian, Mongol (the Oirat included), Yakut as well as the Nenets etiological legends the cow or bull is the embodiment of the severe frost, or is considered responsible for the existence of the winter. In the Tuvinian and Yakut myths the mean bull is directly opposed to the good horse who desired the warmth (Benningsen 1912: 55-57; Ergis 1974: 149; Katash 1978: 18-19; Kulakovski 1979: 73, 77-78; Lehtisalo 1998: 16; Potanin 1883: 203; 1972: 54-55; Taube 2004: 19).

On the contrary, among the Indo-Europeans of Europe, the Northern Caucasus and Central Asia (Ancient Greeks, Serbs, Bulgarians, Gagauz, Ukrainians, Byelorussians, Poles, Czechs, Germans of Mecklenburg, Silesia and East Prussia, Norwegians, Danes, Swedes, Lithuanians, Latvians, Ossetians, Tajik) as well as in the Middle Persian Avestan tradition the horse is considered to be the adversary of God (Balzamo 2011: 78, 85; Balzamo \& Kaiser 2004: 104-106; Belova 2004: 176; Bulashev 1909: 401; Bulgakovski 1890: 189; Chubinski 1872: 49; Chunakova 2004: 110, 216; Dähnhardt 1907: 341-342; 1909: 88-94; Grynblat \& Gurski 1983: 53; Moshkov 2004: 204-205, 261; Petrovich 2004: 183-184; 
Pogodin 1895: 439; Shevchenko 1936: 92; Stoinev 2006: 163; Sukhareva 1975: 39-40; Vèlius 1981: 263; Vukichevich 1915: 109-111; Zaglada 1929: 12) and demonic cannibal horses are described in narratives (Apollod., II, 5, 8; Biazyrov 1971: 156-173). The Baltic Finns (Estonians, Finns, Veps, Sami of Finland) and Komi probably borrowed these ideas from their Indo-European neighbors (Dähnhardt 1907: 155; 1909: 91-92; Limerov 2005: 68-70, 74-76; Vinokurova 2006: 274) but the Ugric groups of Siberia as well as the peoples of the Middle Volga were probably not influenced by them. According to Mordvinian beliefs, seeing a horse in a dream is a sign of disease (Devyatkina 2004: 113) but otherwise the status of the horse in the Mordvinian worldview is high and associations are positive. In the Ancient Greece, just like among the Siberian Turks, the bull was contrasted with the horse but the signs in this opposition were different (Gunda 1979: 398-399). The bull was considered good (bees emerged from its corpse) and the horse bad (wasps or drones emerged). Adopted by the Christian traditions of Central, Northern and Eastern Europe, the opposition between the horse and the bull was used in folktales about the birth of Christ and the travelling Christ who was in search of an animal to help him to cross a river. The bull tried to cover the baby Christ with a hay or straw while the horse pulled it off making him visible for potential persecutors. The horse refused to help Christ to cross a river while the bull helped him.

One of the Norwegian tales contains some of the motifs found in the South Asian and Caucasian myths described above. The devil decided to create a beast that would run across the whole earth and destroy human beings. He tried to make this monster alive by spitting on it but in vain. God made it alive, told it to become a horse and to serve the man. Horny swellings on the horse' hooves are the trace of the Devil's spit (Dähnhardt 1907: 342). In the 19th century Scandinavia the negative associations of the horse were hardly strong. In most of the tales in which the opposition between the horse and the bull is mentioned the horse is bad and the bull is good but there are also texts according to which it was the bull who refused to help Virgin Mary while the horse helped her (Dähnhardt 1909: 94). However across most of Baltoscandia, Ukraine, Byelorussia, as well as Tajikistan we find direct claims that the horse was the only animal created by the devil or that it is the incarnation of the devil himself. Here are some eloquent examples.

Lithuanians. The horse originates from Velnias (the devil) and is eager to kill the man. Velnias rides a horse, can take the image of the horse, different objects in his possession turn into parts of the horse's body: a gun into a leg, a gun's strap into bowels, a tobacco box into a hoof, festive food into dung, etc. (Vèlius 1981: 263-264). 
Byelorussians. A man was harrowing, the devil sat on his harrow and it could not be moved from the place. God transformed the devil into the horse and since then horses exist (Grynblat \& Gurski 1983: 53).

Ukrainians. The horse is a transformed devil. Devil could take any form but God performed magic and the devil remained in the guise of a horse (Chubinski 1872: 49). The horse is an unclean animal. People put sanctified objects under the new cattle-shed to drive away witches. However, they do not put anything sacred in the stable because the devil lives there (Shevchenko 1936: 92).

Tajik. If a man sees a horse in his dream, he falls ill. In Samarkand people do not permit children to approach horses because the horse itself is a dev, i.e. an evil spirit, an ogre (Sukhareva 1975: 39-40).

There are no parallels for the 19th century "horse as a devil" theme in "Edda" but a well-known episode according to which Loki turned into a mare, copulated with a horse of a giant and gave birth to the eight-legged Sleipnir can be interpreted as an evidence in favor of the negative associations with the horse in the early Scandinavian tradition. To which extent the Eddic mythology reflects the set of stories known to the Germanic people in the pre-Christian times is of course impossible to say.

\section{THE NORTHERN TRADITION}

The Northern tradition is widespread across Eastern Europe and Siberia besides Taimyr and the Northeast (Figure 1). It looks like an upside-down version of the Southern tradition.

The well-known variant is as follows. The creator makes bodies of people, puts the dog to guard them and goes away for a while. The antagonist bribes the guard with a warm fur-coat, gets to the bodies and spits on them, making people subject to diseases and death. Coming back, the creator turns the bodies inside out so that the dirt would be concealed from the sight and punishes the dog who since then is a servant of the man and eats garbage.

The Estonian versions are marginal to the tradition in question and do not mention a dog or any other guide of the human figure. The Setu preserved the motif of the devil (vanapagan) who spat on the figure when the creator put it to dry and went away and in another variant the devil simply poked the figure (with his finger) making human body sensible to the pain (Masing 1998: 64).

The story about the creation of the man and the punishment of the dog has been recorded in its typical form in Kazakhstan though it has been recorded in such a form among the Russians of the central and northern parts of European Russia, the Ukrainians, Byelorussians, Komi, Udmurt, Mari, Mordvinians, 
Chuvash, Mansi, Khanty, Nenets, western Evenki, different groups of the Yakuts, the Russian-speaking half-breeds of Russkoye Ust'e (Lower Indigirka), Kumandins, Tubalar, Khakas, Tofa, Buryats (Aktsorin 1991: 38; anonymous 1858: 210; Azbelev \& Mescherski 1986: 214; Belova 2004: 226-227; Devyatkina 1998: 169, 297-298; 2004: 121; Dobrovol'ski 1891: 230-231; Golovnev 1995: 399-400; 2004: 100; Gomboev 1890: 67-69; Grynblat \& Gurski 1983: 46-47; Gurvich 1977: 195-196; Katanov 1963: 155-156; Konakov et al. 2004: 44, 271272; Kuznetsova 1998: 99, 101, 160; Lukina 1990: 300; Middendorff 1989: 20; Morokhov 1998: 427; Perevozchikova 1988: 39; P.I[vanov] 1892: 89-90; Potanin 1883: 220-223; Radlov 1907: 523-524; 1989: 221; Rassadin 1996: 16; Rochev 1984: 114; Sedova 1982: 13-15; Vasiliev 1907: 50-51; Vereschagin 1996: 134; Vladykin 1994: 321-322; Yegorov 1995: 117-118). The same tale was probably known to the Lithuanians, though the corresponding publication has but a short retelling (Kerbelyte 2001: 76). Some variants preserve the core of the story but add different details. In particular, the motif of turning the human body inside out can be used only in those variants according to which the creator himself makes the human figures alive. If the figures are made alive not by the creator but by his adversary, or if the problem was to make people strong and durable and not only to make them alive, the motif of turning the bodies inside out is unfit for the plot. It is absent among the Khanty, most of the groups of the Nenets and Evenki, the Mongols, Altai, Shor, Negidal, and Lamut (Anokhin 1924: 18; Chadaeva 1990: 124; Ivanovski 1891: 251; Khasanova \& Pevnov 2003: 51-53; Khlopina 1978: 71-72; Labanauskas 1995: 13-15; Lar 2001: 188-205; Lehtisalo 1998: 9-10; Mazin 1984: 22; Neniang 1997: 21-23; Nikiforov 1915: 241; Potanin 1883: 218-220; Romanova \& Myreeva 1971: 25-326; Shtygashev 1894: 7-8; Vasilevich 1959: 175-179; Verbitski 1893: 92-93). Among the western Evenki several different versions are recorded besides the standard one (Vasilevich 1959: 175, 178). According to one of them, certain "workers" of Khargi (the creator) let Kheveki (the antagonist) approach the human figures. In another version, the "assistant" of Kheveki is the raven who was punished by the creator the same way as the dog in more typical variants, i.e. since then it has been feeding on garbage.

This story has not been reported from Kazakhstan though it was recorded among the "Siberian Kirghiz". The devil made the weather terribly cold, the dog had to hide itself and the devil spat on the man. Coming back, the creator did not punish the guard but recognized that the dog couldn't have done anything having no fur-coat, so the creator himself and not the antagonist gave to the dog its fur (Ivanovski 1891: 250). "The acquittal" of the dog puts this version apart from the usual Siberian cases. 
The farthest from the basic scheme is the Oroch version located at the eastern periphery of the tale's spread area and isolated territorially from the others (Avrorin \& Lebedeva 1966: 195-196). In the Oroch text the dog itself proves to be the antagonist because, despite the creator's warning, it itself fed the man and made him alive. As a result, people lost the hard covering on their skin that is now preserved only on the fingers and toes (the nails). The text of the southern Selkup leaves the impression of being distorted and partially forgotten: loz (a devil) makes the dog to change its skin which originally was as hard as the nails of the humans (Pelikh 1972: 341). Northing is told about the destiny of the man himself.

Despite the obvious Christian Apocrypha elements in some texts, the ultimate origin of corresponding motifs cannot be attributed to the late Christian influence. The names of protagonists in the Siberian and Volga-Permian versions are not borrowed from the Russians but belong to the local mythological personages. The Northern tradition looks like being derived from the Southern one but with the dog's role in creation of the man radically changed. In the southern versions the dog successfully drives the antagonists away while in the northern versions it betrays the man and is punished for this. The punishment itself is the same as the punishment of the horse in the southern versions, both animals must serve the man and suffer bad treatment and a lack of good food. The positive role of the dog corresponds to its high status in the Zoroastrianism and probably among the Bronze Age Indo-Europeans. The change of its role to the negative one probably reflects the transformation of the plot thanks to its adaptation to a different cultural milieu. This process can be provisionally dated to the I millennium A.D. when the ethnic situation in the Steppe zone changed and the influence of the "Abrahamian" religions began to be felt across a large part of the continental Eurasia.

\section{CONCLUSIONS}

There is but one historical scenario capable to explain parallels between the South Asian, Caucasian, European-Siberian and other variants of the mythological tale about the creation of the human figures by God and an attempt of antagonists to destroy them. The areas where different versions of the tale have been recorded, are separated from each other by the Eurasian steppe belt. Therefore just these steppe territories could be the area of the initial spread of the story. 
The terminus ante quem for the emergence of the tale is defined by the time of contacts between the people of the steppe origin and the inhabitants of South Asia.

In the Bronze Age groups of the steppe cattle breeders who were familiar with the domestic horse penetrated South Asia where they came into contact with the speakers of Munda languages. Taking into consideration all the evidence from the Caucasus, Hindu Kush and Mongolia, we can contend that the tale about the creation of man typical for the Munda people was borrowed by the South Asian natives from the early Indo-European migrants and was formerly widespread across the Eurasian steppes. In South Asia, some groups of the speakers of the Tibeto-Burman and Dravidian languages also borrowed it, either directly from the Indo-Europeans (possibly from the Dards) or already from the Munda. In some later traditions the ancient anthropogonic tale was incorporated into the Christian or Muslim beliefs and brought to such distant territories as Maghreb and Maluku.

In the I millennium A.D. a new, the Northern, variety of this tale emerged. The dog, who originally was a successful guard of the man, was transformed into the betrayer and acquired all the negative associations that were initially related to the horse. This variant spread across the forest zone of Eurasia from the Baltic to the Pacific. In the steppes, however, the pre-Turkic and pre-Islamic anthropogenic tales almost totally disappeared, their unique trace being the Oirat story from western Mongolia.

The hypothesis according to which early Indo-Europeans were familiar with a tale about a good dog and a bad horse does not contradict a suggestion shared by most of the scholars concerning a high ritual status of the horse in the IndoEuropean cultures. At least two possibilities should be considered. The horse could have been originally domesticated not by the Indo-Europeans but by some other groups, thence its associations with hostile forces. Or the horse could have been domesticated by the Indo-Europeans, but before this it was a game animal and a part of the wild and non-human world. For parallels we can address the American Indian myths in which the big game animals like buffaloes or tapirs usually play a role of dangerous antagonists. Such stories also coexisted with an important role of the buffalo in the Plains Indians' rituals.

In any case I am convinced that the only way to reconstruct the mythology of the people who lived in the past is a search of its survivals in the later folklore. The analysis of ancient iconography or scraps of evidence preserved in the early written sources is not enough for the reconstruction of the plots of complex tales. 


\section{ACKNOWLEDGEMENTS}

Russian Fund for Basic Research no. 14-06-00247.

\section{REFERENCES}

Aceval, Nora 2005. Contes et tradicions d'Algérie. Paris: Flies France.

Aktsorin, Vitali A. 1991. Mariiski folklor. [Mari Folklore.] Yoshkar-Ola: Mariiskoe knizhnoe izdatelstvo.

Anokhin, Andrei V. 1924. Materialy po shamanstvu u altaitsev. [Materials on the Shamanism among the Altai.] Leningrad: Museum of Anthropology and Ethnography.

Anonymous 1858. O religii nekreschenyh cheremis Kazanskoi gubernii. [About the Religion of the Non-Babtised Cheremissians of Kazanprovince.] Etnograficheski sbornik. 4th ed. Saint Petersburg: Imperatorskoe Russkoe Geograficheskoe Obcshestvo, pp. 209-218.

Avrorin, Valentin A. \& Lebedeva, Elena P. 1966. Orochskie skazki i mify. [Oroch Tales and Myths.] Novosibirsk: Nauka.

Azbelev, Sergei N. \& Mescherski, Nikita A. 1986. Folk'klor Russkogo Ust'ia. [Folklore of Russkoe Ustie.] Leningrad: Nauka.

Baarda, M.J. van 1904. Lòdasche texten en varhalen. Bijdrachen tot de Taal-, Land- en Volkenkunde van Nederlandisch-Indie, Vol. 56, No. 3-4, pp. 392-493.

Balzamo, Elena 2011. Contes et légendes de Suède. Paris: Flies France. 223 p.

Balzamo, Elena \& Kaiser, Reinhard 2004. Contes et légendes d'Allemagne, Suisse et Autriche. Paris: Flies France.

Benningsen, A. P. 1912. Legendy i skazki Tsentralnoi Azii, sobrannye grafom A. P. Benningsenom. [Legends and Tales of Central Asia Collected by Count A. P. Benningsen.] Saint Petersburg: Tipografia A. S. Suvorina.

Belova, Olga V. 2004. Narodnaia Biblia. [The Folk Bible.] Moscow: Indrik.

Berezkin, Yuri 2010. Mifologicheskie ob'yasnenia smertnosti cheloveka i problema proiskhozhdenia na-dene. [Mythological Explanations of the Mortal Nature of Man and Problem of the Na-Dene Origins.] Ot bytiya $k$ inobytiyu. Fol'klor $i$ pogrebal'ny obriad v traditsionnyh kul'turah Sibiri i Ameriki. Saint Petersburg: Peter the Great Museum of Anthropology and Ethnology, pp. 7-50.

Biazyrov, Alexander Kh. 1972. Osetinskie narodnye skazki. [Ossetian Folktales.] Tskhinvali: Yryston.

Boyce, Mary A 1989. Persian Stronghold of Zoroastrianism. Lanham \& New York \& London: University Press of America.

Bryant, Edwin 2001. The Quest for the Origins of Vedic Culture. The Indo-Aryan Migration Debate. Oxford, New York: Oxford University Press.

Bulashev, Georgi O. 1909. Ukrainski narod v svoih legendah i religioznyh vozzreniah $i$ verovaniah. Iss. 1. [Ukrainian People in its Legends and Religious Views and Beliefs, Vol. 1.] Kosmogonicheskie ukrainskie narodnye vozzrenia i verovonia. [Cosmogonic Ukrainian Folk Views and Beliefs.] Kiev: Universitet sv. Vladimira. 
Bulgakovski, Dmitri G. 1890. Pinchuki. Etnograficheski sbornik. [The Pinchuks. Ethnographic Collection.] Saint Petersburg: Imperatorskoe Russkoe Geograficheskoe Obschestvo.

Chadaeva, Alina Ya. 1990. Drevni svet. Skazki, legendy, predania narodov Khabarovskogo kraia. [The Ancient Light. Folktales, Legends, Traditions of the Peoples of Khabarovsk Region.] Khabarovsk: Khabarovskoe knizhnoe izdatel'stvo.

Chubinski, Pavel P. 1872. Trudy etnografichesko-statisticheskoi ekspeditsii v Zapadnorusski kray. Yugo-zapadnyi otdel. Materialy i issledovania sobrannye P. P. Chubinskim. [Transactions of Ethnograpfic-Statistical Expedition to West-Russian Region. Southwestern Department. Materials and Studies of P. P. Chubinski.] Vol. 1. Saint Petersburg: Imperatorskoe Russkoe Geograficheskoe Obschestvo.

Chunakova, Olga M. 2004. Pehleviiski slovar' zoroastriiskih terminov, mificheskih personazhei $i$ mifologicheskih simvolov. [The Pahlevi Dictionary of the Zoroastrian Terms, Mythical Personages and Mythological Symbols.] Moscow: Vostochnaya literatura.

Dähnhardt, Oskar 1907. Natursagen, Vol. 1. Leipzig \& Berlin: Teubner.

Dähnhardt, Oskar 1909. Natursagen, Vol. 2. Leipzig \& Berlin: Teubner.

Devyatkina, Tatyana 1998. Mifologia mordvy. [Mythology of the Mordvinians.] Saransk: Krasny Oktiabr.

Devyatkina, Tatyana 2004. Mordvinian Mythology. Ljubljana: Založba ZRC Publishing.

Diffloth, Gérard 2005. The Contribution of Linguistic Palaeontology to the Homeland of Austro-Asiatic. The Peopling of East Asia. London \& New York: Routledge Curzon, pp. 79-82.

Dobrovol'ski, Vladimir N. 1891. Smolenski etnograficheski sbornik. [Smolensk Ethnographic Collection.] Vol. 2. Peterburg: Tipografia Yevdokimova.

Dolgikh, Boris O. 1952. Proishozhdenie nganasanov. [Origins of the Nganasans.] Sibirski etnograficheski sbornik. Moscow \& Leningrad: Institut Etnografii AN SSSR, pp. $5-87$.

Dolgikh, Boris O. 1976. Mifologicheskie skazki i istoricheskie predania nganasan. [Mythological Tales and Historic Legends of the Nganasans.] Moscow: Nauka.

Dubova, Nadezhda A. 2012. Pogrebenia zhivotnyh v strane Margush. [Animal Burials in the Margush Country.] Transactions of Margiana Archaeological Expedition, Vol. 4, pp. 101-139.

Ergis, Georgi U. 1974. Ocherki po yakutskomu folkloru. [Essays on Yakut Folklore.] Moscow: Nauka.

Golovnev, Andrey V. 1995. Govoriaschie kultury. Traditsii samodiitsev i ugrov. [Speaking Cultures. Traditions of Samoyed and Ugric People.] Yekaterinburg: UrO RAN

Gomboyev, Galsan. 1890. Skazania buriat, zapisannye raznymi sobirateliami. [Buryat Legends Recorded by Different Collectors.] Irkutsk: Vostochno-Sibirski Otdel Imperatorskogo Russkogo Geograficheskogo Obschestva po etnografii.

Grynblat, M. Ya. \& Gurski, A. I. 1983. Legendy i padanni. [Legends and Traditions.] Minsk: Navuka i tehnika.

Gunda, Béla 1979. Ethnographica Carpatho-Balcanica. Budapest: Akadémiai Kiadó.

Gurvich, Ilia S. 1977. Kultura severnyh yakutov-olenevodov. [Culture of the Northern Reindeer Yakuts.] Moscow: Nauka.

Hermanns, Matthias P. 1954. The Indo-Tibetans. Bombay: Fernandes. 
Howey, M. Oldfield 1923. The Horse in Magic and Myth. London \& Aylesbury: William Ridey \& Sons.

Ivanovski, A. A. 1891. K voprosu o dualisticheskih pover'iah o mirozdanii. [To a Question about Dualistic Cosmogonic Beliefs.] Etnograficheskoe obozrenie, Vol. 9, No. 2, pp. 250-252.

Jettmar, Karl 1986. Religii Gindukusha. [Religions of Hindu Kush.] Moscow: Nauka. (Translated from: Die Religionen des Gindukusch von Karl Jettmar. Stuttgart \& Köln \& Meinz: Verlag W. Kohlhammer, 1975.)

Kapp, Dieter B. 1977. Ein Menschenschöpfungsmythos der Mundas und seine Parallelen. Wiesbaden: Franz Steiner.

Kapp, Dieter B. 1986. A parallel motif in Lepcha and Barela-Bhilala mythology. Asian Folklore Studies, Vol. 45, No. 2, pp. 259-285.

Katanov, Nikolai F. 1963. Khakasski folklor. [The Khakas Folklore.] Abakan: Khakasskoe knizhnoe izdatelstvo.

Katash, Sergei S. 1978. Mify, legendy Gornogo Altaia. [Mountain Altai Myths and Legends.] Gorno-Altaisk: Gorno-altaiskoe otdelenie Altaiskogo knizhnogo izdatelstva, 1978.

Kerbelyte, Bronislava 2001. The Types of Folk Legends. Saint Petersburg: Evropeiskiy Dom.

Khasanova, Marina \& Pevnov, Alexander 2003. Mify i skazki negidal'tsev. [Myths and Tales of the Negidals.] Kyoto: Nakanishi Printing Co.

Khlopina, I. D. 1978. Iz mifologii i traditsionnyh religioznyh verovanii shortsev. [From Mythology and Traditional Religious Beliefs of the Shor.] Etnoghrafia narodov Altaia i Zapadnoi Sibiri. Novosibirsk: Nauka, pp. 70-89.

Konakov, Nikolai D., et al. 2003. Komi Mythology. Budapest: Akadémiai Kiadó \& Helsinki: Finnish Literature Society.

Koppers, Wilhelm \& Jungblut, Leonard 1976. Bowmen of Mid-India. Wien: Institut für Völkerkunde.

Kriukova, Viktoria Yu. 2005. Zoroastrism. [The Zoroastrinism.] Saint Petersburg: Azbuka-Klassika, Peterburgskoe Vostokovedenie.

Kruijt, Albertus C. 1906. Het animisme in den Indischen archipel. 's-Gravenhage: M. Nijhoff.

Kulakovski, Alexei E. 1979. Nauchnye trudy. [Scientific Works.] Yakutsk: Yakutskoe knizhnoe izdatel'stvo.

Kuzmina, Elena K. 2000. The Eurasian Steppes. The Transition from Early Urbanism to Nomadism. Kurgans, Ritual Sites, and Settlements: Eurasian Bronze and Iron Age. Oxford: Archeopress, pp. 118-125. (BAR International Series 890.)

Kuzmina, Elena K. 2008. Arii - Put' na yug. [The Arians on the Way to the South.] Moscow: Letni sad.

Kuzmina, Elena K. 2010. Kul'tura Margiany i Baktrii epohi final'noi bronzy v rabotah V. I. Sarianidi. [Cultures of Margiana and Bactria of the Terminal Bronze Age in V. I. Sarianidi's works.] Na Puti Otkrytia Tsivilizatsii. Saint Petersburg: Aleteia, pp. 29-38.

Kuznetsova, Vera S. 1998. Dualisticheskie legendy o sotvorenii mira v vostochnoslavianskoi fol'klornoi traditsii. [Dualistic Legends about the World Creation in the East Slavic Folklore Tradition.] Novosibirsk: SO RAN. 
Labanauskas, Kazimir I. 1995. Nenetski fol'klor. [The Nenets Folklore.] Krasnoyarsk: Administratsia Taymyrskogo avtonomnogo okruga.

Lar, Leonid A. 2001. Mify i predania nentsev Yamala. [Myths and Legends of the Nenets of Yamal.] Tiumen': Institut problem osvoenia Severa of SO RAN.

Lehtisalo, Toivo 1998. Mifologia yurako-samoyedov (nentsev). Tomsk: Tomski Universitet. (Translated from Lehtisalo, T. 1924. Entwurf einer Mythologie der JurakSamoeden. Helsinki.)

Limerov, Pavel F. 2005. Mu puks'om - Sotvorenie mira. [Mu puks'om - Creation of the World.] Syktyvkar: Komi knizhnoe izdatelstvo.

Litvinski, Boris A. \& Sedov, Alexander V. 1984. Kul'ty i ritualy kushanskoi Baktrii. [Cults and Rituals of Kushan Bactria.] Moscow: Nauka.

Lukina, Nadezhda V. 1990. Mify, predania, skazki khantov i mansi. [Myths, Legends, Tales of the Khanty and Mansi.] Moscow: Nauka.

Masing, Uku 1998. Eesti usund. [Estonian Folk Religion.] Tallinn: Ilmamaa.

Mazin, Anatoli I. 1984. Traditsionnye verovania i obriady evenkov-orochonov. [Traditional Beliefs and Rituals of the Orochon Evenki.] Novosibirsk: Nauka.

Middendorff, Alexander 1989. Korennye zhiteli Sibiri. Yakuty. [Siberian Natives. The Yakuts.] Yakutski Fol'klor. Khrestomatia. Yakutsk: Yakutski gosudarstvenny universitet, pp. 21-22.

Molodin, Viacheslav I. 2003. Etnogenez, etnicheskaia istoria i istoricheskie sud'by nositelei pazyrykskoi kul'tury Gornogo Altaia. [Ethnogenesis, Ethnic History and Historic Future of the Bearers of the Pazyryk Culture of the Altai highlands.] Naselenie Gornogo Altaia v epohu rannego zheleznogo veka kak etnokul'turny fenomen. Novosibirsk: SO RAN, pp. 148-178.

Morokhov, Vladimir N. 1998. Legendy $i$ predania Volgi-reki. [Legends and Traditions of Volga River.] Nizhni Novgorod: Nizhegorodskaia Yarmarka.

Moshkov, Valentin A. 2004. Gagauzy Benderskogo uyezda. [The Gagauz of Bendery District.] Kishinev: Tipografia Centrală.

Napolskih, Vladimir V. 1997. Vvedenie v istoricheskuiu uralistiku. [Introduction to the Historic Uralic Studies.] Izhevsk: UrO RAN.

Neniang, Liubov' P. 1997. Khodiachi um naroda. Skazki, legendy, mify, predania, epicheskie pesni, poslovitsy, pogovorki, poveria, oberegi, narodnye primety, zagadki taimyrskih nentsev. [People's Shifting Intelligence. Folktales, Legends, Myths, Traditions, Epic Songs, Proverbs, Sayings, Beliefs, Amulets, Omens, Riddles of Taimyr Nenets.] Krasnoyarsk: Fond severnyh literatur "HEGLEN".

Nikiforov, Nikolai Ya. 1915. Anosski sbornik. Sobranie skazok altaitsev. [The Anos Collection of Altai Folktales.] Omsk: Zapadno-Sibirski Otdel Imperatorskogo Russkogo Geograficheskogo Obschestva.

Osada, Toshiki 2010. A comparative study of Munda creation myth. Paper presented for Radcliffe Exploratory Seminar on Comparative Mythology. October 6-7, 2010. Cambridge: Cambridge University, pp. 1-12.

Osada, Toshiki \& Onishi, Masayuki 2010. Language Atlas of South Asia. Kyoto: Research Institute for Humanity and Nature.

Parpola, Asko \& Janhunen, Juha 2010. On the Asiatic Wild Asses (Equus hemionus \& Equus kiang) and Their Vernacular Names. Na Puti Otkrytia Tsivilizatsii. Saint Petersburg: Aleteia, pp. 423-466. 
Pelikh, Galina I. 1972. Proiskhozhdenie selkupov. [The Origins of the Sel'kup.] Tomsk: Izdatelstvo Tomskogo universiteta.

Perevozchikova, Tatiana G. 1988. Melodia nebesnoi rosy. [Melody of the Sky Dew.] Izhevsk: Udmurtia.

Peterson, John 2009. Kharia-English Lexicon. Santa Barbara: University of California. Petrovič, Sreten 2004. Srpska mitologia. [Serbian Mythology.] Beograd: Narodna knega Alfa - Neven.

P.I[vanov] 1892. Iz oblasti malorusskih narodnyh legend. [From Ukrainian Folk Legends.] Etnograficheskoe obozrenie, Vol. 13-14, No. 2-3, pp. 15-97.

Pinegina, M. \& Konenkin, Georgi 1952. Evenkiiskie skazki. [The Evenki Folk-tales.] Chita: Chitgiz.

Pinnow, Heinz-Jürgen 1965. Kharia-Texte. Wiesbaden: Harrassowitz.

Playfair, Alan 1909. The Garos. London: D. Nutt.

Pogodin, A. 1895. Kosmicheskie legendy baltiiskih narodov. [Cosmic Legends of Baltic Peoples.] Zhivaia starina, Vols. 3-4, pp. 428-448.

Popov, Andrei A. 1984. Nganasany. [The Nganasans.] Leningrad: Nauka.

Potanin, Grigori N. 1883. Ocherki severo-zapadnoi Mongolii. Vypusk IV. Materialy etnograficheskie. [Northwest Mongolia Essays. Ethnographic Materials.] St. Petersburg: tipografia Kirshbauma.

Potanin, Grigori N. 1972. Kazakhski folklor v sobranii G.N. Potanina. [Kazakh Folklore from G. N. Potanin's Collection.] Alma Ata: Nauka.

Radlov, Vassili V. 1907. Obraztsy narodnoi literatury tiurkskih plemen. [Samples of the Folk Literature of the Turkic Tribes.] Part IX. Saint Petersburg: Imperatorskaia Akademia Nauk.

Radlov, Vassili V. 1989. Iz Sibiri. Stranitsy dneunika. Moscow: Nauka. 750 p. (Translated from Aus Siberien. Lose Blätter aus meinen Tagebuche von Dr Wilhelm Radloff. Leipzig, 1893).

Rassadin, Valentin I. 1996. Legendy, skazki i pesni sedogo Sayana. Tofalarski folklor. [Legends, Folktales and Songs of Old Sayan. The Tofa Folklor.] Irkutsk: Irkutskaia oblastnaia administratsia.

Rochev, Yuri G. 1984. Komi predania i legendy. [Komi Traditions and Legends.] Syktyvkar: Komi knizhnoe izdatel'stvo.

Romanova, Agnia V. \& Myreeva, Anna N. 1971. Fol'klor evenkov Yakutii. [Folklor of the Evenki of Yakutia.] Leningrad: Ykutski filial Sibirskogo otdelenia AN SSSR.

Sedova, Lidia V. 1982. Legendy $i$ predania mordvy. [Legends and Traditions of the Mordvinians.] Saransk: Mordovskoe knizhnoe izdatel'stvo.

Shakespear, J. 1909. Folk-tales of the Lushais and Their Neighbours. Folk-Lore, Vol. 20, No. 4, pp. 388-420.

Shevchenko, Liudmila 1926. Zvychai zviazani z zakladynamy budivli. [Customs related to the Foundation of a House.] Pervisne gromadianstvo ta yogo perezhitki na Ukraini. Kyiv: Derzhavne vydavnttstvo Ukrainy, Vol. 1-2, pp. 87-95.

Shtygashev, Ioann 1894. Predania inirodtsev Kuznetskogo okruga o sotvorenii mira i pervogo cheloveka. [Traditions of the Natives of Kuznetsk District about the Creation of the World and of the First Man.] Zapiski Zapadno-Sibirskogo otdelenia Rossiskogo Geograficheskogo Obschestva, Vol. 17, No. 1. Omsk. 12 p. (Separate pagination for every article.) 
Simms, Stephen C. 1906. Myths of the Bungees or Swampy Indians of Lake Winnipeg. Journal of American Folklore, Vol. 19, No. 75, pp. 334-340.

Skorodumova, Lidia G. 2003. Skazki i mify Mongolii. [Folktales and Myths of Mongolia.] Ulaanbaatar: Monsudar.

Soppitt, C. A. 1995. An Historical and Descriptive Account of the Kachari Tribes in the North Achar Hills. Shillong: Assam Secretariat Printing Office.

Stoinev, Anani 2006. B'lgarska mitologia. [Bulgarian Mythology.] Sofia: Zakhari Stoyanov.

Sukhareva, Olga A. 1975. Perezhitki demonologii i shamanstva u ravninnyh tadzhikov. [Relicts of Demonology and Shamanism among the Lowland Tajik.] Domusul'manskie verovania i obriady v Srednei Azii. Moscow: Nauka, pp. 5-93.

Taube, Erika. 2004. Volksmärchen der Mongolen. München: Biblion Verlag.

Vasilevich, Glafira M. 1959. Rannie predstavlenia o mire u evenkov. [Early Ideas About the World Among the Evenks.] Trudy Instituta Etnografii, Vol. 51, pp. 157-192.

Vasiliev, M. 1907. Religioznye verovania cheremis. [Religious beliefs of the Cheremissians.] Ufa: Gubernskaia tipografia. $54 \mathrm{p}$.

Vèlius, Norbertas 1981. Velnio banda: 'stado vial'niasa'. [Velnio banda: 'The Herd of Velnias'.] Balto-slavianskie issledovania 1980. Moscow: Nauka, pp. 260-269.

Verbitski, Vasili I. 1893. Altaiskie inorodtsy. [The Altai Natives.] Moscow: Skoropechatnia Levinsona.

Vereschagin, Grigori 1995. Votiaki Sosnovskogo kraya. [The Votiaks of Sosnovo Region.] Izhevsk: UrO RAN.

Vladykin, Vladimir 1994. Religiozno-mifologicheskaia kartina mira udmurtov. [The Religious-mythological Worldview of the Udmurts.] Izhevsk: Udmurtia.

Vinokurova, Irina Yu. 2006. Zhivotnye $v$ traditsionnom mirovozzrenii vepsov. [Animals in Traditional Worldview of the Veps.] Petrozavodsk: Izdatel'stvo PetrGU.

Vukichevich, Mil. M. 1915. Serbskaya legenda o dvuh tsarstvah - Bozhiem i Diavola. [Serbian Legend about Two Kingdoms, One of the God and One of the Devil.] Zhivaia starina, Vol. 1-2, pp. 101-114.

Yegorov, Nikolai I. 1995. Chuvashskaia mifologia. [The Chuvash Mythology.] Kul'tura Chuvashskogo Kraia. Cheboksary: Chuvashskoe knizhnoe izdatel'stvo, pp. 109146.

Zaglada, Nina 1929. Pobut selian'skoi dytyny. [Everyday Life of a Peasant.] Kyiv: "KyivDruk".

Zhamkochian, [Bishop] Anushavan 2012. The Bible and the Armenian Oral Tradition. Yerevan: Yerevan State University [in Armenian]. 